\title{
POTENT NON-PROTONOPHORE UNCOUPLERS ACTING ON NATURAL AND ARTIFICIAL MEMBRANES
}

\author{
Jean-Marc Roltaboll, Georges Talllandier,* Patrick Ravanel + and Michel Tisslt \\ Laboratoire de Physiologie Cellulaire Vëgètale (URA au C.VRS 576), Lniversite Joseph Fourier-Grenoble I, B.P. 53 X, 33041 \\ Grenoble Cèdex. France: +Laboratoire de Pharmacognosie. "Laboratoire de Chimie Organique, Lniversite Joseph Fourier- \\ Grenoble I. Domaine de la Merci, 38700 La Tronche, France
}

(Receiced in retised form $12 \mathrm{Jul} ; \mathrm{1993)}$

Key Word Index-Solanum tuberosum; Solanaceae: Spinacia oleracea, Chenopodiaceae; uncoupling activity; plant mitochondria: thylakoids; cells; liposomes; phenylureas.

\begin{abstract}
The uncoupling properties of 10 new symmetrical phenylureas, including $N . N$-bis- -4 -trifluoromethylphenyl)-urea, were investigated. Four compounds were shown to be powerful uncouple:s. The result is a proton transfer across the organelle's membrane. These symmetrical phenylureas cannot be classified among the main class of uncouplers (acting through a protonophoric mechanism), due to their inability to exchange protons in a range of pHs between 2 and 9 . The most potent uncouplers of the series induced permeabilization of artificial bilayer membranes (without protein) to both $\mathrm{H}^{-}$and monovalent cations $\left(\mathrm{K}^{+}, \mathrm{Na}^{+}\right)$and did not increase the rate of diffusion of a small uncharged molecule (urea). The uncoupling properties for such molecules are due neither to their ability to induce conformational changes in membrane protein nor to their effect on phospholipid bilayer fluidity. They seem to change the regular organization of the polar lipid bilayer.
\end{abstract}

\section{INTRODLCTION}

In a previous paper [1]. we described some biological properties of a symmetrical phenylurea: $\mathrm{N}, \mathrm{N} \cdot$-bis- +4 trifluoromethylphenyl)-urea (USp $C_{3}$ ). Among several interesting activities which were observed in isolated organelles, this compound was shown to be a highly potent uncoupler. The result of its action is a proton transfer through the biological membrane, leading to a collapse of the proton gradient required for ATP synthesis. The effectiveness of this compound is comparable to the protonophore reference uncoupler CCCP [2] or to platanetin, a natural lipophilic flavonoid extracted from plane-tree buds [3] but its mode of action is different: the symmetrical phenylurea being a non-protonophore. The physiological interest of this molecule led us to synthesize and study 10 derivatives of the same family including the $\mathrm{N.X}$-bis-if-trifluoromethylphenyli-urea. It seems to be of a great importance for the understanding of the uncoupling mechanism to know how such non-ionizable compounds can uncouple organelles. For this purpose. this paper reports some fur: her investigations on artificial bilayer membranes in an attempt to gain insight into the molecular mechanism by which this molecule can induce a proton transfer across the biological membranes. Their mode of action could be to bring about a conformationa! change in the transmembrane protains. leading to a $\mathrm{H}^{\text {- }}$

+ Aather to whom cortespostence should be addressed. permeability $[4,5]$ or a change in the organization or activity of the phospholipid bila:s: [6]

\section{RESLLTS}

\section{Physical constants of the symmetrical phenylureas}

The ability of the symmetrica! phenylureas to ionize was studied. In order to do this. UV spectral shifts dependent on $\mathrm{pH}$ change (between 2 and 9 ) were looked for. No significant spectral variations were observed. This indicated that the symmetrical phenylureas, such as $\mathrm{LS}_{p} \mathrm{CF}_{3}[1]$. are unable to ionize. Similar results were obtained by a classical titrimetris method.

We also determined the lipophilicity of the compounds by three methods. The partition coefficien: $P$. expressed b) $\log P$ (a conventional measutement of the lipophilietty), (11 was measured spectropitotumet:cally through octanol water partitioning. The measurement of the lipofrilicity by the partitioning method is neither an aceurate roo an essy technique for such highly lipophilic comfounds. Only three derivatives were measured by this method with sufficient accuracy: (2) was estimated by reversal phase TLC on silica-C $\mathrm{C}$ ( $\mathrm{MeOH}-\mathrm{H}_{2} \mathrm{O}, 17: 3$ and (3) was calculated theoretical!; by a method derived from ref. [7]. All the log $P$ salues ate given in Table 1 . The $\log P$ values differ depending on the method used, although there were good correlations between all these 
J.-M. ROUTABOUL et al.

Table $1 . \log P$ values for the symmetrical phenylureas studied

\begin{tabular}{llll}
\hline Substitution & $\begin{array}{l}\text { Estimated by } \\
\text { chromatography }\end{array}$ & $\begin{array}{l}\text { Measured by } \\
\text { spectrophotometry }\end{array}$ & Calculated \\
\hline $4-\mathrm{CF}_{3}$ & 3.30 & 3.80 & 5.12 \\
$3,4-\mathrm{diCl}_{3}$ & 4.30 & & 5.83 \\
3-CF & 2.95 & 3.30 & 5.12 \\
4-Cl & 3.20 & & 4.34 \\
3- $\mathrm{Me}$ & 3.15 & & 4.34 \\
3-OMe & 2.60 & 2.35 & 3.90 \\
Lnsubstituted & 2.25 & 2.70 & 3.02 \\
4-OMe & 1.95 & & 2.86 \\
$4-\mathrm{Me}$ & 2.60 & & 3.02 \\
\hline
\end{tabular}

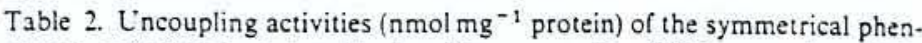
ylureas on isolated potato mitochondria measured by $50 \%$ uncoupling of the respiration rate with $6 \mathrm{mM}$ succinate (+ATP $0.3 \mathrm{mM}$ ) as substrate, or by $100 \%$ swelling in a $\mathrm{NH}_{4} \mathrm{Cl}$ or $\mathrm{NH}_{4} \mathrm{NO}_{3}$ isoosmotic medium

\begin{tabular}{|c|c|c|c|}
\hline Substitution & Common name & $\begin{array}{l}D_{50} \\
50 \% \text { uncoupling }\end{array}$ & $100 \%$ swelling \\
\hline $4-\mathrm{CF}_{3}$ & $\mathrm{LSpCF}_{3}$ & 5.9 & 11 \\
\hline 3.4-diCl & LSm.pCl & 7.7 & 18 \\
\hline $3 \cdot \mathrm{CF}_{3}$ & $\mathrm{LSmCF}$ & 10 & 18 \\
\hline $3 \cdot \mathrm{Cl}$ & $\mathrm{LSmCl}$ & 14 & 18 \\
\hline $4 \cdot \mathrm{Cl}$ & $\mathrm{LSpCl}$ & 34 & 50 \\
\hline $3 . \mathrm{Me}$ & LSm.Me & 183 & - \\
\hline \multirow[t]{2}{*}{ 3.OMe } & USmOMe & 318 & - \\
\hline & LSm.pH & 818 & - \\
\hline \multicolumn{4}{|l|}{ Unsubstituted } \\
\hline 4.OMe & LSpOMe & - & - \\
\hline $4-\mathrm{Me}$ & LSpMe & - & - \\
\hline
\end{tabular}

- Vio uncoupling activity even at saturating concentration.

values:

$\log P$ estimated by chromatography $=0.605 \log P$ calculated $+0.353(n=10, r=0.91)$

$\log P$ calculated $=2.096 \log P$ measured spectrophotometrically $-2.730(n=3, r=0.99)$

(n: number of values, $r$ : regression coeficient).

Lncoupling activity the symeirical phenturess on nituchondria

Table 2 summarizes the uncoupling activities of the symmetrical phen: lureas on isolated mitochondria. Four derivatives, ....'bis-(4-trifluoromethylphenyl)urea ( $\mathrm{LS}_{p} \mathrm{CF}_{3}$ ). $\times$...bis-(3.4-dichiorophenyl)-urea (LSm.pCl). … N-bis-(3-trifluoromethylphenyl)-urea (LSm $\mathrm{CF}_{3}$ ), $\therefore, \cdots$-bis-(3-chloropheny)-ures ( $\mathrm{LSmCl}$ caused complete uncoupling of electron transfer in mito. chondria oxidizing suctinate at concentrations lower or

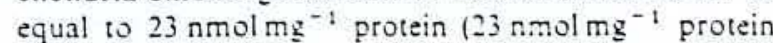
being the concentration required with CCCP to obtain complete uncouplingl. The same results were obtained when succinate was replaced by $x$-ketoglutarate or mal- ate. During oxidation of exogenous NADH. the bigh inhibitory activity of some of these products on electron transfer could rapidly mask their uncoupling activity.

Concurrent spectrophotometric measurement of mi: chondrial swelling in $\mathrm{NH}_{4} \mathrm{Cl}$ or $\mathrm{NH}_{4} \mathrm{NO}_{3}$ isoosmotic media [1.8] confirmed the uncoupling activity demonstrated by polarography (Table 2). The same concentrations of these four poweriul phenylureas increased in the same way the $O_{2}$ consumption with succinate or the mitochondrial swelling in isoosmotic media containing $\mathrm{NH}_{4}{ }^{-}$ions (complete uncoupling Has given by the reference protonophore uncoupler (CCP). The result of the symmetrical phenylureas action is a proton transfer across the mitochondrial membrane. The other deriva:ives were weak uncouplers or were without effest (Table 2). 
Table 3. Comparison of the uncoupling and inhibitory activities (nmol $\mathrm{mg}^{-1}$ chlorophyll) of the symmetrical phenylureas on thylakoids and class $\mathrm{A}$ chloroplasts

\begin{tabular}{|c|c|c|c|}
\hline Common name & $\begin{array}{l}\text { Class A chlor. } \\
I_{30} \\
50 \% \text { inhibition }\end{array}$ & $\begin{array}{l}I_{30} \\
50 \% \text { inhibition }\end{array}$ & $\begin{array}{l}\text { Thylakoids } \\
D_{\text {so }} \\
50 \% \text { uncoupling }\end{array}$ \\
\hline $\mathrm{US}_{p} \mathrm{CF}_{3}$ & 8.7 & 250 & 10.9 \\
\hline $\mathrm{US} m . p \mathrm{Cl}$ & 17.4 & 125 & 17.4 \\
\hline $\mathrm{US}_{m} \mathrm{CF}_{3}$ & 26.1 & 162 & 21.7 \\
\hline $\mathrm{USmCl}$ & 34.8 & 375 & 39.1 \\
\hline $\mathrm{US}, \mathrm{Cl}$ & - & - & 174 \\
\hline USmMe & - & 2500 & 869 \\
\hline USmOMe & - & 3750 & 1522 \\
\hline $\mathrm{LSm}, \mathrm{pH}$ & - & 4375 & 1739 \\
\hline USpOMe & - & - & 4783 \\
\hline USple & - & - & - \\
\hline
\end{tabular}

- No uncoupling effect even at saturating concentration.

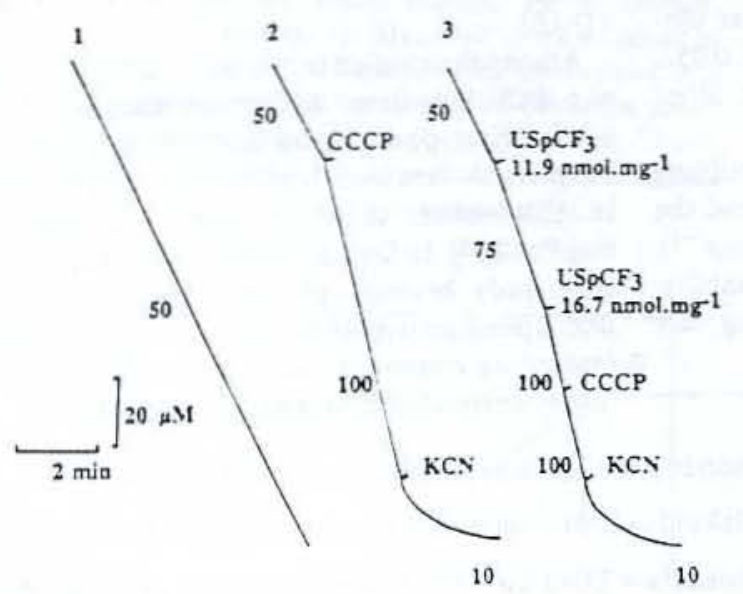

Fig. 1. Polarographic traces showing the uncoupling activity of USpCF, on Acer cells $\left(0.45 \mathrm{mg}\right.$ protein $\left.\mathrm{ml}^{-1}\right)$. (1) Respiratory control trace; (2) respiratory centrol trace in the presence of CCCP $\left(10.4 \mathrm{nmol} \mathrm{mg} \mathrm{m}^{-1}\right.$ protein): (3) respiratory trace in the presence of $\mathrm{LSpCF}_{3}$. Numbers on the traces refer to nmol $\mathrm{O}_{2}$ consumed $\mathrm{min}^{-1} \mathrm{mg}^{-1}$ protein. KCN: $100 \mu \mathrm{M}$.

Lncoupling and inhibitury detitity of the s!mmetrical phenylureas on thylakvids and ihloroplasts

Table 3 summarizes the inhibitory and the uncoupling activities of symmetrica! phenylureas on isolated thylakoids and on light-driven $\mathrm{O}$ : evolution in intact chloreplasts. For each of the four most active compounds, a similar concentration $\mathrm{w}$ as required to inhibit $\mathrm{O}_{2}$ evolution in class A chloroplasts and to uncouple the phos. phorylation process in thylaksids. Moreover, the inhibition of electron transfer from $\mathrm{H}_{2} \mathrm{O}$ to methylviologen in uncoupled thylakoids (in the presence of $5 \mathrm{mM} \mathrm{NH}_{4} \mathrm{Cl}$ ) occurred at much higher concentrations and this inhibition of electron transfer could not explain the inhibition of photosynthesis in intact chloroplasts. As for USpCF, [1]. We demonstrated that all the symmetrical pheny!- ureas inhibiting electron transfer in thylakoids were acting at the level of photosystem II (PS II) and were inactive on photosystem I (PS I) (results not shown). These results suggested that uncoupling of the photophosphorylation process was directly responsible for the inhibition of the whole photosynthetic mechanism shown by $\mathrm{O}_{2}$ evolution in class $\mathrm{A}$ chloroplasts.

Uncoupling actitity of the symmetrical phenylureus, in situ. on a suspension culture of Acer pseudoplatanus cambial cells

A dense suspension of Acer cells was put into the reaction vessel of an oxygen electrode. The oxygen consumption of such a suspension. which reached $50 \mathrm{nmol} \mathrm{O} \mathrm{min}^{-1} \mathrm{mg}^{-1}$ protein, was greatly increased by $10.4 \mathrm{nmol}$ CCCP $\mathrm{mg}^{-1}$ protein and was fully suppressed by $\mathrm{KCN} 100 \mu \mathrm{M}$ (Fig. 1). Under the same experimental conditions, 16.7. 26.2. 32.5 and $48.1 \mathrm{nmol} \mathrm{mg}^{-1}$ protein of $\mathrm{US}_{p} \mathrm{CF}_{3}, \mathrm{USm}, p \mathrm{Cl}$. USm $\mathrm{CF}_{3}$ and $\mathrm{USmCl}$. respectively, induced the same increase of the cyanidesensitive respiratory rate as that obtained with $C$ CCP.

Permeabilization of artificial bildyer mimibrare to cations by the symmetrical phenyluress

Liposomes are usually impermeable to frotons and this was the case for the soya lecthin liposomes used in this study. Hinkle's method $[\vartheta]$ show's that the permeabilization of liposomes to cations can be obtained after addition of an uncoupler. We foilowed the electron transfer between an external hydrophilic reductor unable to penetrate into liposomes (sodium ascorbate) and a hydrophilic acceptor enclosed in liposomes (fotassium ferricyanide) with a lipophilic electron carrier (tetramethyl-p-phenylenediamine: TMPD) which can easily cross the artificial membrane. The transmembrane $\mathrm{H}^{*}$ gradient limits strictly the electron transfer across the membrane. The uncoupler inducing $\mathrm{a} \mathrm{H}^{-}$permeabiliz- 
ation. suppresses the transmembrane charge gradient, and consequently increases the ferricyanide reduction rate. $\mathrm{US} p \mathrm{CF}_{3}(25 \mu \mathrm{M})$ induced a 3.2 -fold increase in the average reduction rate of the inner ferricyanide

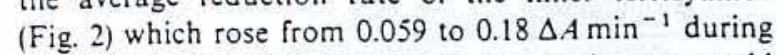
the first $4 \mathrm{~min}$. This increase corresponds to a rapid transfer of cations across the liposome membrane. Under the same experimental conditions, USm,pCl, $\mathrm{US}_{m} \mathrm{CF}_{3}$. US $m \mathrm{Cl}$ and $\mathrm{USpCl}$ induced an increase in the reduction rate of $0.140,0.122,0.082,0.045 \Delta .4 \mathrm{~min}^{-1}$, respectively. Other symmetrical phenylurea derivatives were without effect. For comparison, the protonophore reference uncoupler platanetin. at $25 \mu \mathrm{M}$. induced an increase in the ferricyanide reduction rate which was only 1.5 -fold higher $\left(0.065 \mathrm{Am} \mathrm{min}^{-1}\right)$ than that of the untreated sample.

Similar results were obtained when measuring the liposome swelling rate in isoosmotic $\mathrm{NH}_{4} \mathrm{Cl}$ medium. Figure 2 shows that $25 \mu \mathrm{M}$ of $\mathrm{USp}_{p} \mathrm{CF}_{3}$ induced an average swelling rate of $0.11 \Delta \mathrm{A} \mathrm{min} \mathrm{m}^{-1}$ during the first 4 min when the untreated sample remained unchanged. Under the same experimental conditions, USm,p Cl, $\mathrm{US}_{m} \mathrm{CF}_{3}$. US $m \mathrm{Cl}, \mathrm{US} p \mathrm{Cl}$ and reference uncoupler platanetin induced an average rate of swelling of $0.085,0.055$, $0.030,0.028,0.065 \Delta .4 \mathrm{~min}^{-1}$, respectively. The other products of the series were ineffective.

Correlations were studied between the uncoupling activity on organelles and cells $\left(D_{50}: \mathrm{nmol} \mathrm{mg}^{-1}\right)$ and the induction of liposome $\mathrm{H}^{-}$permeabilization $\left(1.4 \mathrm{~min}^{-1}\right)$. The best correlations were found with the permeabilization values obtained with the liposome swelling rate
Reference $\mathrm{K}^{+}$carrier, valinomycin, at $25 \mu \mathrm{M}$, induced an average rate of swelling of $0.055 \Delta \mathrm{Amin}^{-1}$.

\section{Modification of the membrane fluidity}

Liposomes spontaneously swell in a urea isoosmotic medium. This small molecule, without charge, diffuses slowly across the membrane inducing a change in the osmotic pressure and as a consequence an influx of water. Addition of $\mathrm{USp}_{\mathrm{C}} \mathrm{CF}_{3}$ did not change the speed of penetration of urea suggesting that the symmetrical phenylurea did not modify the membrane fluidity. Even after a $15 \mathrm{~min}$ incubation period with the symmetrical phenylurea, the penetration rate of urea remained unchanged.

\section{Disclssio.y}

Several derivatives of the symmetrical phenylurea series studied here are among the most powerful uncouplers of phosphorylation processes. Due to their non-ionizability, these highly lipophilic compounds $[1,10]$ cannot transport $\mathrm{H}^{-}$directly as classical uncouplers do [2. $11-16]$.

Among the studied series, only por $m \mathrm{CF}_{3}, p$ or $m \mathrm{Cl}$ or $m . p \mathrm{diCl}$ derivatives are potent uncouplers. The other symmetrical phenylureas are almost ineffective as uncouplers. A very high lipophilicity seems to be required. in this series, to show potent uncoupling action $(\log P>4.34)$. In fact, a multiple linear regression correlation study between physico-chemical parameters and uncoupling activity in thylakoids and mitechondria gave interesting equations with $\log P$ or $\Sigma \sigma$ values ( $\Sigma \sigma$ being highly correlated here with $\log P: r=0.34)$ :

$$
\begin{gathered}
\log 1 / D_{50} \text { mitochondria }=0.734 \log P+1.856(n=8, r=0.938, s=0.308 . F=43.55) \\
\log 1 D_{s 0} \text { thylakoids }=0.912 \log P+1.44 !(n=10 . r=0.886, s=0.513, F=29.16) \\
\log 1, D_{50} \text { mitochondria }=3.040 \sum \sigma+4.185(n=8, r=0.920, s=0.346 . F=33.10) \\
\log 1 D_{50} \text { thylakoids }=3.307 \sum \sigma+4.637(n=10 . r=0.963 . s=0.297 . F=103.27) .
\end{gathered}
$$

measurement (Fig. 3). The high degree of correlation found with the best equation $(r=0.99)$ suggests an identical mode of action of the studied compounds on liposomes, organelles and on fier cells.
In marked contrast, none of the parameters used to express the shape of the molecule (length. width, volume. etc.) was able to give valuable equations.

$D_{\text {so }}$ mitochondria $=0.299 \mathrm{H}^{-}$permeabilization $-3.297 \quad(n=4 . r=0.985$ )

$$
\begin{aligned}
D_{s 0} \text { thylakoids } & =0.109 \mathrm{H}^{*} \text { permeabilization }-0.261(n=4, r=0.993) \\
D_{\text {so }} \text { cells } & =0.775 \mathrm{H}^{-} \text {permeabilization }-6.283(n=4 . r=0.985) .
\end{aligned}
$$

Swelling experiments on liposomes were performed not only with $\mathrm{NH}_{4} \mathrm{Cl}$ but also with $\mathrm{NH}_{4} \mathrm{NO}_{3} . \mathrm{KCl}$, $\mathrm{NaCl}$. $\mathrm{NH}_{4} \mathrm{H}_{2} \mathrm{PO}_{4}$ and $\left(\mathrm{NH}_{4}\right)$ : $\mathrm{SO}_{4}$ isoosmotic media (Fig $\rightarrow$ ). For example, $\mathrm{L}: \mathrm{S}_{2} \mathrm{CF}_{3}$ was both an uncoupler (in $\mathrm{NH}_{4} \mathrm{NO}_{3}$ and $\mathrm{NH}_{4} \mathrm{Cl}$ and an ionophore able to induce fermeabilization of lifosome membranes to $\mathrm{K}^{-}$ $\left(0.1 \Delta .4 \mathrm{~min}^{-1}\right)$ and $\mathrm{Ni}_{3}^{-}\left(0.0651 . \mathrm{Amin}^{-1}\right)$. In contrast. platanetin, a potent uncoupler. is not an ionophore [10].
As the hypothesis of a direct $\mathrm{H}^{-}$transmembrane ransport was ruled out (no $\mathrm{pKa}$ in the biological $\mathrm{pH}$ rangel, the mode of action of these uncouplers could involve an effect eithe: on the proteic part of the membranes or on the polar lipids. Liposomes, exelusivedy constituted of polar lipid bilayers. were used to demonstrate whether the polar lipids were involved in the 


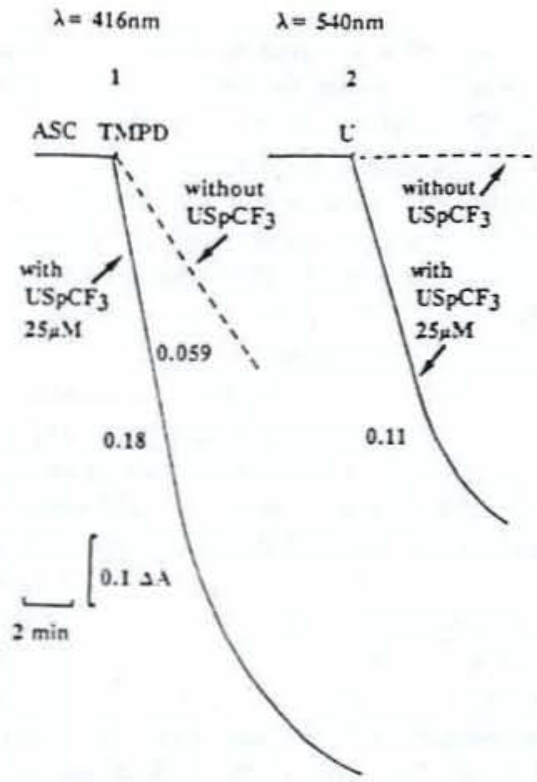

Fig. 2. Spectrophotometric traces showing the permeabiliz. ation of liposomes to protons. (1) Measured by the reduction of the potassium ferricyanide: (2) measured by the swelling in a $\mathrm{NH}_{4} \mathrm{Cl}$ isoosmotic medium. $\mathrm{L}$ : uncoupler; $\mathrm{ASC}$ : sodium ascorbate $5 \mathrm{mM:}$ : TMPD: tetramethyl-p-phenylenediamine $25 \mu \mathrm{M}$. Numbers on traces refer to the average change in the absorbance observed for the first $4 \min \left(\Delta+\min ^{-1}\right)$.

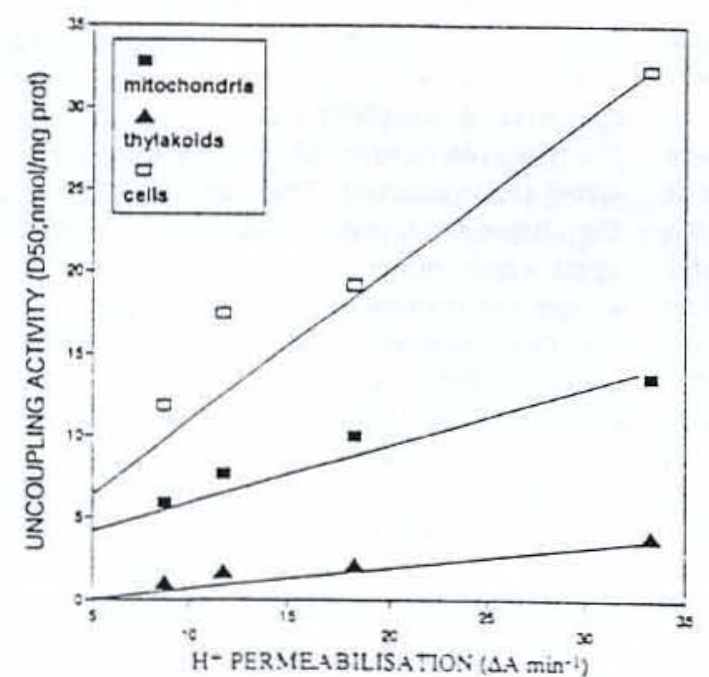

Fig. 3. Compartson betiteen liposome permesbilization to protons measured by suelling in isoosmotic medium and the uncoupling actwity measured on A.tr cells. potato mitochon. dris and on thylakoids for the fou: most fotent symmetrical phenyluress

uncoupling effect with the studied products. Our multilamellar vesicles were shoun to be highly impervious to protons. The symmetric phenylureas found to be uncouplers in the organelles were also uncouplers in the liposomes, the concentrations needed in this latter case being five- to 10 -times higher than those required for a

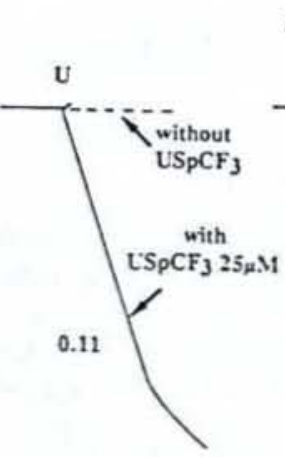

$\mathrm{NH}_{4} \mathrm{Cl}$ $\lambda=540 \mathrm{~nm}$
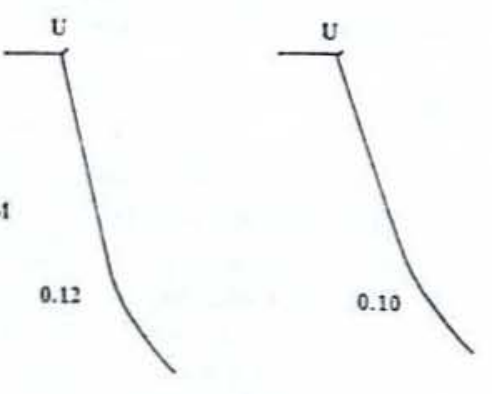

$\mathrm{kC}$

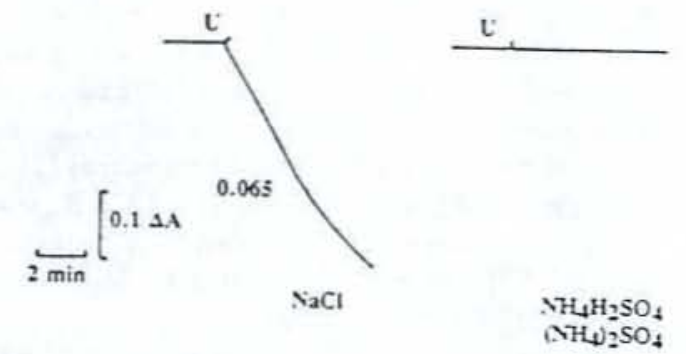

Fig, 4. Spectrophotometric suelling traces showing the rermea. bilization of a liposome isoosmotic suspension to protons and cations after addition of $\mathrm{L}^{\prime} \mathrm{S}_{\mathrm{CF}}$. L: uncoupler. Numbers on traces refer to the average change in the absorbance observed for the first $4 \min \left(\Delta+\min ^{-1}\right)$.

complete uncoupling of organelles. The analog: of the uncoupling effect on isolated mitochondria, thy!akoids, Acer cells and liposomes is sufficient to suggest that, in each case, the uncoupling process was the same.

The symmetrical phenylureas are thus potent nonionophore uncouplers which paradoxically fossess a mode of action both specific enough to induce permeabilization to some monovalent cations and not to other charged or uncharged molecules and unspecific and simple enough to act on different membranes including even the simplest one, the liposome. The only requirement seems to be the lipophilicity, even if the inefficiency of the pOMe and the p.Me derivatives suggests that some steric exigencies could exist. Our results ruled out the hypothesis than the uncoupling effect could te due to a high affinity binding site on membrane protein components [4. 5].

The hypothesis of a detergent effect of these substances remains unlikely as their effect is quite different from classical compounds such as Trion $X-100[1--19]$. The membrane permeability to $\mathrm{H}^{*} . \mathrm{N}_{3}{ }^{-}$and $\mathrm{K}^{-}$seems to originate from the binding of the phenyluteas to the polar lipids, therefore perturbating the strict orsanization of the bilayer membranes. The possibility of an extra molecular link between the $-\mathrm{NH}$ and or the - $\mathrm{CO}$ group of the phenylurea with the phospholipid components has to be considered [6]. However, the permeability of the phos. pholipid bilayer to $\mathrm{H}^{*}$ could also the the result of the 
formation of stable phenylurea dimers inside the lipophilic membrane space.

\section{EXPERIMENTAL}

Synthesis. Symmetrical phenylureas were synthesized as previously described [1] by reaction of substituted phenylisocyanate with substituted aniline.

Loy $\mathrm{P}$ measurement. Experimental values of $\mathrm{US}_{p} \mathrm{CF}_{3}$. $\mathrm{USm} . \mathrm{pH}$ and $\mathrm{USm} \mathrm{Cl}$ were obtained in an octanol/water system as previously described. after spectrophotometric measurements $[1,20]$. Log $P$ values of other products were estimated by reversal phase TLC (silica-C18. MeOH-H, O, 17:3). The $R_{m}$ values used to determine $-\log P$ were obtained using the equation: $R_{\mathrm{m}}=\log \left(1 R_{\mathrm{f}}-1\right)$. The standard curve was constructed with 8 reference compounds (phenylcarbamate, metobromuron, metoxuron, diuron, naphthalene, chlortoluron. phenanthrene, bibenzyl). The correlation equation between the $-\log P$ values of the 8 standards $[21,22]$ and the measured $R_{\mathrm{m}}$ was: $\log P=3.771+2.826 R_{\mathrm{m}}(r=0.981)$. Log $P$ values were also calculated by a method derived from ref. [7]. using the experimental $-\log P$ value given by ref. [21] for biphenylurea.

$\mathrm{pKa}$ measurement. Experimental values of $\mathrm{pKa}$ were looked for according to ref. [1].

Preparation of chloroplasts. Spinach (Spinacia oleracea L. Chenopodiaceae) leaves class $A$ and $C$ chloroplasts were obtained as previously described [23].

Preparation of mitochondria. Mfitochondria from potato tubers (Solanum tuberosum L.. Solanaceae) were prepared by methods previously described [24].

$\mathrm{O}_{2}$ exchange measurements. $\mathrm{O}_{2}$ exhcange was followed polarographically at $25^{\circ}$, using a Clark-type electrode system. For plant mitochondria, the reaction medium contained $0.3 \mathrm{M}$ mannitol, $5 \mathrm{mM} \mathrm{MgCl} .10 \mathrm{m.M} \mathrm{KCl}$, $10 \mathrm{m.M}$ Pi buffer. and $0.1 \% \mathrm{BS}$. A . All the incubations were carried out at $\mathrm{pH} 7.2$. For measuring photosynthetic $\mathrm{O}_{2}$ exchange, the reaction medium contained $0.3 \mathrm{M}$ mannitol. $50 \mathrm{~m}$ M MOPS (morpholinopropane sulphonic acid). $2 \mathrm{mM}$ EDT.A. $\mathrm{pH}$ 7.6. The release of $\mathrm{O}$, by class $\mathrm{A}$ chloroplasts was measured after the addition of $0.5 \mathrm{mM}$ $\mathrm{NaHCO}_{3}$ and $0.1 \mathrm{m.M} \mathrm{Na}_{2} \mathrm{HPO}_{4}$. In thylakoid membranes ( $23 \mu \mathrm{g}$ chlorophy $\| \mathrm{mi}^{-1}$ medium). electron transfer was measured on uncoupled organelles $\mathrm{N}_{4} \mathrm{Cl}$. $5 \mathrm{mMl}$. in the presence of the electron acceptor methylsiologen (paraquat, $0.1 \mathrm{M}$. KC. $(0.1 \mathrm{~m} . \mathrm{f})$ w as added at the beginning of the erperimen: to inhibit any fossible catalase astivity

Lncuupling tes: for :filatoils. Measurements of the uncoupling effect were r..ude on light-dziven electron fow through PS II - PS I. The uncoupling effect gave rise to an increase in the $\mathrm{O}$ : consumption rate. A $100^{\circ}$ 。 uncoupling effect was sbtained when the addition of $\mathrm{NH}_{4} \mathrm{Cl}(5 \mathrm{mMl})$ did not induce furthe: increases in $\mathrm{O}$ : consumption.

Lnioupling tes: for mitwinonirid A suspension of intact mitochondria was energized. After a state III-state IV transition, the uncoupling effect of the product added at this stage corresponds to an increase in the oridation rate. A $100 \%$ uncoupling effect was obtained when the rate of $\mathrm{O}_{2}$ was not further stimulated by the addition of $\operatorname{CCCP}(5 \mu \mathrm{M})$ or $\mathrm{ADP}(200 \mu \mathrm{M})$.

Mitochondrial swelling. Mitochondrial swelling was measured as previously described [20], by the apparent absorbance decrease at $540 \mathrm{~nm}$. The reaction medium contained $100 \mathrm{mM} \mathrm{NH} \mathrm{NO}_{3}$ or $\mathrm{NH}_{4} \mathrm{Cl}, 15 \mathrm{mM}$ Tris$\mathrm{HCl}, 0.1 \% \mathrm{BS} A, \mathrm{pH} 7.2$. A rapid passive swelling was induced by uncouplers.

Protein and chlorophyll measurements. Protein contents were determined according to ref. [25] and chlorophyll concentration were measured as described in ref. [26].

Preparation of liposomes. Liposomes were prepared from Type II-s and III-s soybean L- $z$-phosphatidylcholine (Sigma) from methods derived from refs $[6,9]$ Phosphatidylcholine $(500 \mathrm{mg})$ was dissolved in $15 \mathrm{ml}$ petrol. The soln was dried under partial vacuum, at room temp. in the dark in an attempt to form a uniform film on the surface of the flask. The film was further stirred, for $3 \mathrm{hr}$, at $25^{3}$, with $10 \mathrm{ml}$ of a dispersion soln $120 \mathrm{mM}$ MOPS [morpholinopropane sulphonic acid]. $1 \mathrm{mM}$ EDTA and $0.6 \mathrm{M}$ mannitol for swelling test or $0.2 \mathrm{M}$ potassium ferricyanide. $\mathrm{pH} 7.5$ ). The liposome suspension was then dialysed for $12 \mathrm{hr}$ against 3 -fold $500 \mathrm{ml} 20 \mathrm{mM}$ MOPS, I mM EDTA, $0.6 \mathrm{M}$ mannitol.

Uncoupling tests for liposomes. Permeabilization to cations of a suspension of liposomes was followed by a method derived from ref. [9]. We followed the electron transfer induced between an hydrophilic reductant (sodium ascorbate) unable to cross the membrane and an acceptor (potassium ferricyanide) included inside the liposomes. A lipophilic electron carrier. tetramethyl-pphenylene diamine (TMPD). transports the electrons across the membrane. The transmembrane charze gradient limits the transfer of electrons. The addition of an agent which induces a fermeabitization to cations, supresses the transmembrane charge gradient increasing the rate of reduction of ferricyanide. The reduction of the potassium ferricyanide was followed spectrophotometrically at $416 \mathrm{~nm}$. Liposome suspension $(50 \mu 1)$ was diluted in $2 \mathrm{ml}$ reaction medium $10.6 \mathrm{M}$ mannitol. $1 \mathrm{~m} . \mathrm{M}$ EDTA. $20 \mathrm{mM}$ MOPS. $\mathrm{pH} 7.5$ ). The included ferricyanide absorbance value of this suspension u 351.9 at $416 \mathrm{~nm}$ in $1 \mathrm{~cm}$ cuvette. After addition of sodium ascorbate $15 \mathrm{mML}$ tetraphenylboron $(20 \mu \mathrm{M})$ and of uncoupler (dissolved in EtOH: final conen in the cuve:te: $10 \%$. the ferticynide reduction started with the add::ion of TMPD i $2 \mu \mathrm{M}$.

Liposome swelling. Liposeme swelling is measured with a technique derived from mitochendita shelling methods [3] by the apparen: absotbane destease a: $540 \mathrm{~nm}$. Liposome suspension $(100 \mu 1)$ in 35 difuted in $2 \mathrm{~m}$ : of the reaction medium containing $0.3 \mathrm{M} \mathrm{NH} . \mathrm{Cl}$ or $\mathrm{YH}_{4} \mathrm{YO}_{3} .1 \mathrm{~m} \mathrm{M}$ EDT 4 and $20 \mathrm{mM} \mathrm{MOPS}$. $\mathrm{FH} 7.5$. The absorbance at $540 \mathrm{~nm}$ us close to 0.9 in a $1 \mathrm{~cm}$ cuvette. A rapid passive sirelling $w a s$ induced by the addition of the uncoupler. The same method was used for the measurement of membrane permeabilization to cations in ith $\mathrm{KC}$. $\mathrm{NaCl}, \mathrm{MgCl}$ : or $\mathrm{CaCl}$ : isvosmotic media.

Q.S.A.R. and?:ris. Correlations between the aztivity of the uncouplers on organelles and some parameters 
describing their physical or chemical properties were calculated using a multilinear regressive analysis. The parameters used were $\log P[7,21], \Sigma \sigma[21],{ }^{1} \chi^{\gamma}$ (molecular connectivity [27]), $\triangle \mathrm{RM}$ (molecular refraction [21]), $L$ and $B$ (length and width of the substituents [28]). $r$. regression coefficient, $s$ : standard deviation of the regression, $t$ : Student's test value, $F: F$ test value.

\section{REFERENCES}

1. Routaboul, J. M., Mougin, C., Ravanel, P., Tissut, M. Mrlina, G. and Calmon, J. P. (1991) Phytochemistry 30, 733 .

2. Terada, H. (1981) Biochim. Biophys. Acta 639, 225 ,

3. Ravanel, P., Tissut, M. and Douce, R. (1986) Plant Physiol. 80, 500.

4. Antalik, M., Sturdik, E., Sulo, P., Propperova, A., Mihalovova, E., Pohradsky, D. and Dzurila, M. (1988) Gen. Physiol. Biophys. 7, 517.

5. Weinbach, E. C. and Garbus, J. (1965) J. Biol. Chem. 240, 1811.

6. Blein, J. P., Ducruet, J. M. and Gauvrit, C. (1979) Weed Res. 18, 327.

7. Rekker, R. F. and Dekort. H. M. (1979) Eur. J. Med. Biochem. 14, 479.

8. Jung, D. W. and Brierly. G. P. (1979) Plant Physiol. 64. 948.

9. Hinkle, P. (1970) Biochem. Biophys. Res. Commun. 41, 1375.

10. Routaboul, J. M. (1991) Thése de Doctorat de I'Université J. Fourier, Grenoble. France.

11. Ravanel, P., Taillandier. G., Tissut, M. and BenoitGuyod, J. L. (1985) Ecotoxicol. Entiron. Safety 9, 300.
12. Me Laughlin, S. and Dilger, J. P. (1980) Physiol. Rev. 60, 825 .

13. Benz, R. and Mc Laughlin, S. (1983) Biophys. J. 41, 381.

14. Finkelstein, A. (1970) Biochim. Biophys. Acta 205, 1.

15. Kasianowicz, J., Benz, R. and Mc Laughlin, S. (1987) J. Membr. Biol. 95, 73.

16. Kasianowicz, J., Benz, R. and Mc Laughlin, S. (1984) J. Membr. Biol. 82, 179.

17. Goni, F. M., Gondra, A., Gurtubay, J. I. G. and Macarulla, J. M. (1980) Int. J. Biochem. 11, 507.

18. Brown, C. and Brand, M. D. (1986) Biochem. J. 234. 75.

19. Matondo, H., Bénévidès, N., Tissut, M., Bergon. M. De Savignac, A., Calmon, J. P. and Lattes, A. (1989) J. Agric. Food Chem. 37, 169.

20. Creuzet, S., Ravanel, P., Tissut, M. and Kaouadji, M. (1987) Phytochemistry 27, 3093.

21. Hansch, C. and Leo, A. (1979) in Substituent Constant for Correlation Analysis in Chemistry and Biology: pp. 1-339. J. Wiley, New York.

22. Mitsutake, H. J., Iwamura, H., Shimizu, R. and Fujita, T. (1986) J. Agric. Food Chem. 34. 725.

23. Nakatani, H. Y. and Barber, J. (1977) Biochim. Biophys. Acta 461, 510.

24. Douce, R., Christensen, E. L. and Bonner, W. D. (1972) Biochim. Biophys. Acta 275, 148.

25. Bradford, N. M. (1976) Anal. Biochem. 72. 248.

26. Arnon, D. I. (1949) Plant Physiol. 24, 1.

27. Kier, L. B. and Hall. L. H. (1986) in Molecslar Connectitity in Structure Actitity Analysis, pp. 1-262. Research Studies Press, J. Wiley, New York.

28. Verloop, A., Hoogenstraaten. W. and Tipker. J. (1976) in Drug Design Vol. 11 (Ariens. B., ed.). pp. 165-207. Academic Press, New York. 